\title{
An Ancestral Caddo Site (41CS125) on the Sulphur River at Lake Wright Patman, Cass County, Texas
}

Julian A. Sitters

Archeology Division, Texas Historical Commission

Timothy K. Perttula

Heritage Research Center, Stephen F. Austin State University

Follow this and additional works at: https://scholarworks.sfasu.edu/ita

Part of the American Material Culture Commons, Archaeological Anthropology Commons, Environmental Studies Commons, Other American Studies Commons, Other Arts and Humanities Commons, Other History of Art, Architecture, and Archaeology Commons, and the United States History Commons

Tell us how this article helped you.

This Article is brought to you for free and open access by the Center for Regional Heritage Research at SFA ScholarWorks. It has been accepted for inclusion in Index of Texas Archaeology: Open Access Gray Literature from the Lone Star State by an authorized editor of SFA ScholarWorks. For more information, please contact cdsscholarworks@sfasu.edu. 
An Ancestral Caddo Site (41CS125) on the Sulphur River at Lake Wright Patman, Cass County, Texas

\section{Creative Commons License}

\section{(c) (1) (8)}

This work is licensed under a Creative Commons Attribution-NonCommercial 4.0 International License 


\title{
An Ancestral Caddo Site (41CS125) on the Sulphur River at Lake Wright Patman, Cass County, Texas
}

\author{
Julian (Drew) Sitters ${ }^{1}$ and Timothy K. Perttula ${ }^{2}$ \\ ${ }^{1}$ Texas Historical Commission \\ ${ }^{2}$ Archeological \& Environmental Consultants, LLC \\ In December 2017, AmaTerra Environmental Inc. conducted an intensive archeological survey of 41CS125, a \\ previously reported ancestral Caddo site at Lake Wright Patman in Cass County, Texas. The work was done at \\ the request of the U. S. Army Corps of Engineers, Fort Worth District in advance of a proposed bank stabilization \\ project. The site was occupied from the Late Paleoindian period through historic times with extensive occupations \\ during the Formative to Early Caddo and Late Caddo periods. Artifacts recovered in the investigations included \\ both arrow and dart points, lithic debitage, bifaces, ground stone, a celt fragment, pitted stone, ceramic sherds, a \\ ceramic bead, charred organic material, unidentified bone fragments, and 19th century historic domestic materials. \\ While the site has been adversely affected through alluvial erosion and looting, survey results indicate that intact \\ components of the site still exist along the northern and western periphery of the landform.
}

\section{Introduction}

Site 41CS125, also known as the Mill Creek, Island Site, Rabbit Island, and the Green Farm site, is a multi-component site at Lake Wright Patman occupied from the Late Paleoindian period through historic times (Figure 1). In this article we discuss the 2017 archeological investigations at the site as part of an ongoing archeological survey of Lake Wright Patman on the Sulphur River in Cass County, Texas (Sitters and Perttula 2018), with a focus on the features and ceramics associated with the ancestral Caddo occupations.

\section{Previous Investigations at 41CS125}

The site was formally recorded by Janson L. McVay, a well-known artifact collector from Texarkana, Texas, who encountered an ancestral Caddo burial washing out of its banks in 1959. Subsequently, McVay and other collectors excavated 41 burial features and their associated grave goods or funerary offerings (Texas Archeological Research Laboratory, University of Texas, Site Files). Since then, the site has been revisited many times by artifact collectors who have recovered, through illegal digging, cultural materials such as ceramic vessels, elbow pipes, and projectile points from its shores.

The first professional archeological investigation at 41CS125 may not have occurred until July 2001 when then U.S. Army Corps of Engineers
(USACE)-Fort Worth District Archeologist, Stephen Austin, surveyed the north and northwestern shoreline of the site. At these locations, he documented three areas where human remains were observed eroding out of the banks, as well as three features he described as dark, clayey pits (Figure 2 and Table 1). In August 2006, $41 \mathrm{CS} 125$ was determined eligible for inclusion in the National Register of Historic Places.

In other professional investigations, Dockall and Fields (2006) documented numerous looter holes at 41CS125 in areas with intact archeological deposits exposed in steep wave-cut erosional benches (Dockall and Fields 2006:57). Then in 2014, archeologists from SEARCH conducted a reconnaissance-level survey of 16 known sites at Wright Patman Lake, including $41 \mathrm{CS} 125$, to better understand the nature of impacts to sites from current and proposed pool level rises (Harrell et al. 2015). SEARCH noted "numerous artifacts (lithic flakes, projectile points, pottery sherds, and fauna) were identified across most of the exposed shoreline with a very dense cluster located on the southwest edge of the island" (Harrell et al. 2015:42). Most recently, AmaTerra Environmental Inc. (Sitters and Perttula 2018) carried out an intensive survey of the site, which consisted of a thorough pedestrian survey and tightly spaced shovel testing. The result of their efforts has produced the most robust artifact assemblage collected from the site by professional archeologists. 


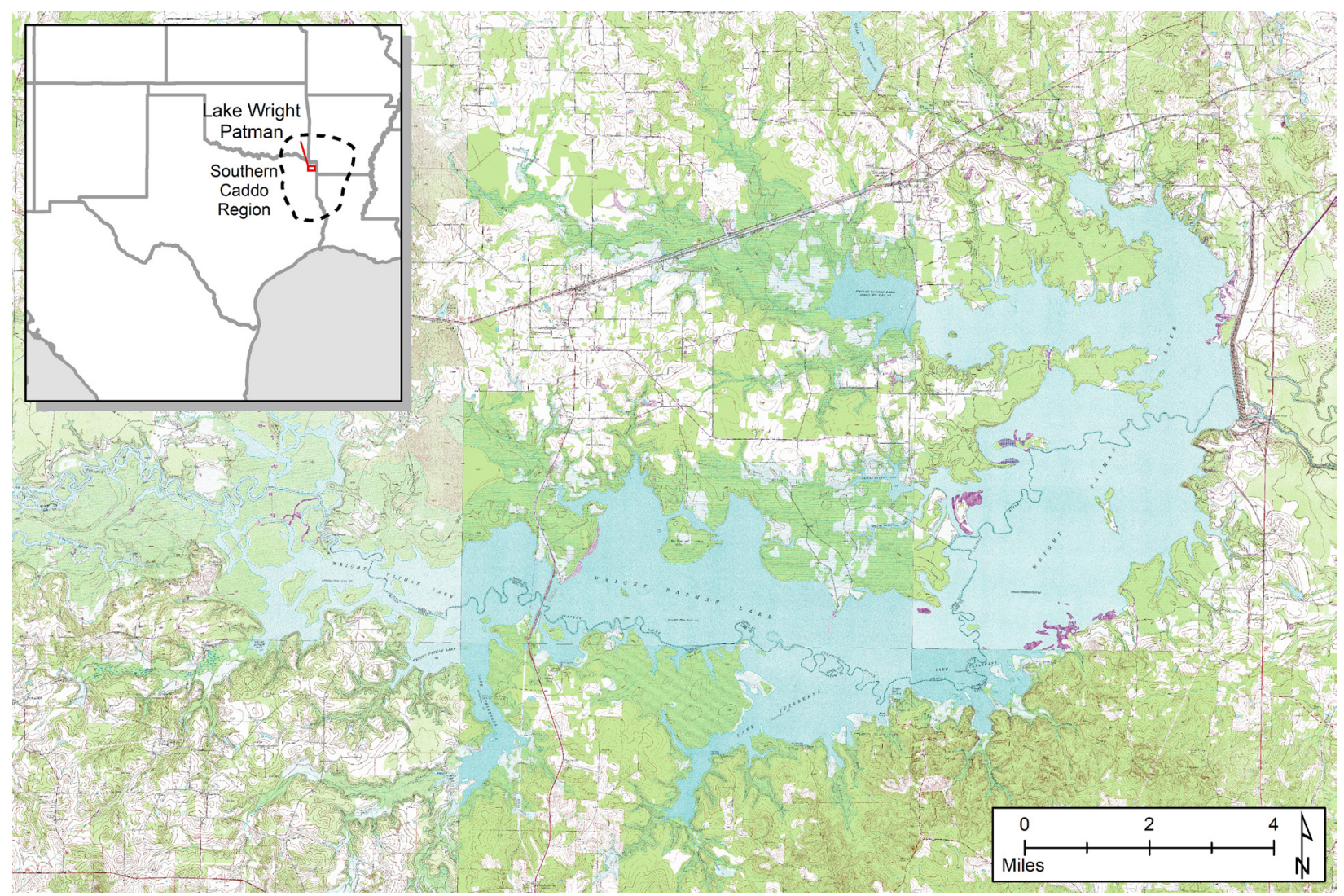

Figure 1. Lake Wright Patman in Bowie and Cass counties, Texas.



Figure 2. Digitized drawing of 41CS125's northern and western shoreline (adapted from Stephen Austin's 2001 hand drawn map).

\section{Archeological Investigations at $41 \mathrm{CS} 125$}

Encompassing 22 acres, the site is on an alluvial terrace landform, surrounded by the waters of Lake Wright Patman. Thus, wave action is causing significant

\begin{tabular}{|c|l|}
\hline Map Reference & Description \\
\hline F1 & $\begin{array}{l}\text { Dark Clayey Pit: No visible evidence } \\
\text { of exposed remains. Some sherds. } \\
\text { Obvious signs of probing. }\end{array}$ \\
\hline F2 & $\begin{array}{l}\text { Probable burial pit. No visible } \\
\text { artifacts, remains, or probing effort. }\end{array}$ \\
\hline F3 & $\begin{array}{l}\text { Probable burial pit. No visible } \\
\text { artifacts, remains, or probing effort. }\end{array}$ \\
\hline Burial 1 & $\begin{array}{l}\text { Proximal portions of humerus placed } \\
\text { side by side next to F1. }\end{array}$ \\
\hline Burial 2 & $\begin{array}{l}\text { Proximal portions of tibia placed at } \\
\text { base of tree on west side of point. No } \\
\text { noticeable burial pit nearby. }\end{array}$ \\
\hline Burial 3 & $\begin{array}{l}\text { Scattered remains. Some sherds and } \\
\text { calcined animal bone fragments }\end{array}$ \\
\hline
\end{tabular}

Table 1. Key to Stephen Austin's 2001 map of 41CS125.

erosion; specifically, along the northern and western banks of the landform (Figure 3) with eroded banks measuring up to one meter in height. On the other hand, the eastern and southern portions of the landform are lower in elevation and susceptible to inundation through the raising and lowering of the lake's water level (Figure 4). Vegetation across the site consists of hardwoods (e.g., oak and willow trees) with an understory composed of shrubs and buttonbush, which line the eastern and southern banks. Ground surface 


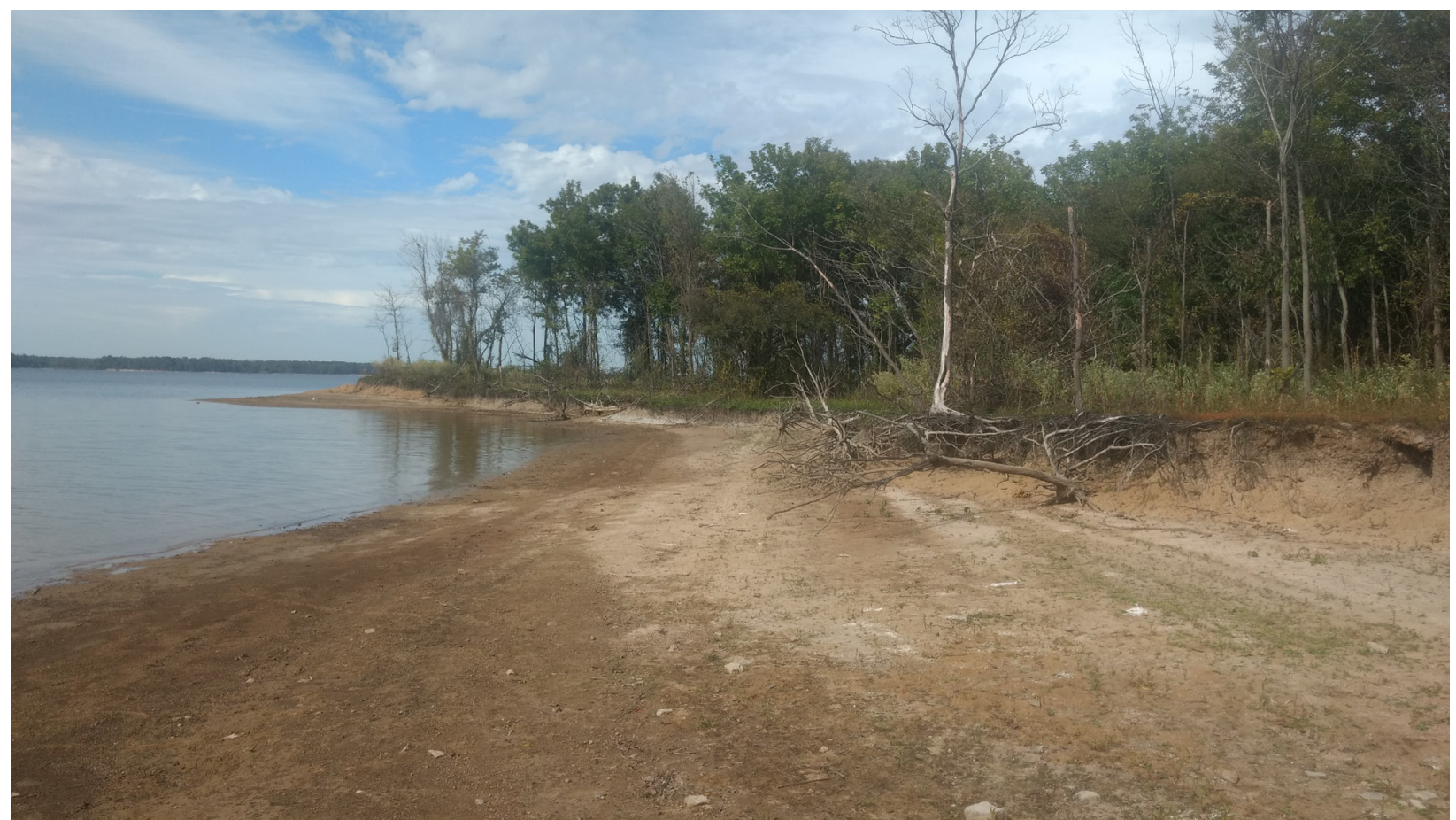

Figure 3. View of 41CS125's western shoreline, photographed facing north.

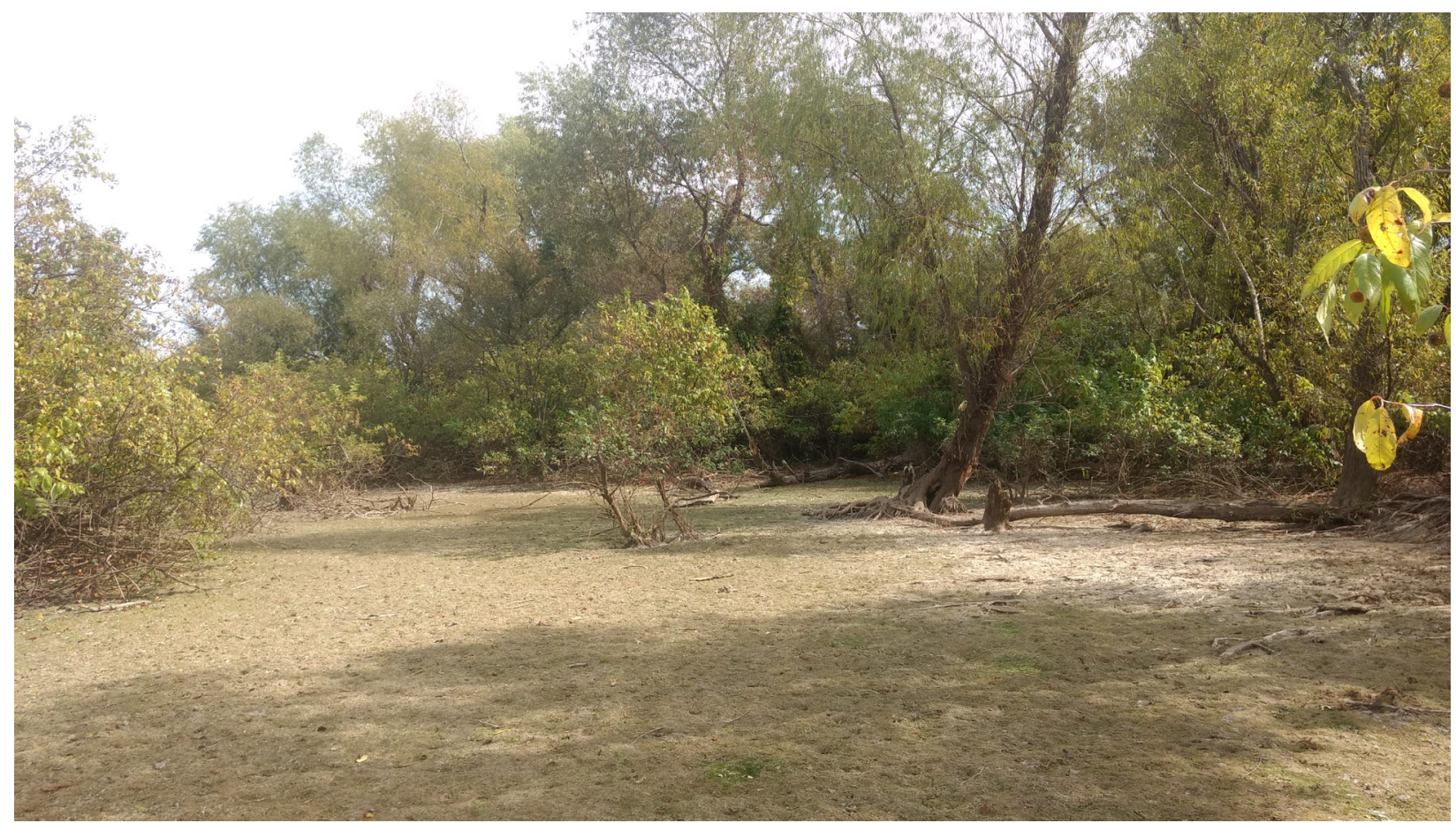

Figure 4. Setting within the southern portion of $41 \mathrm{CS} 125$, photographed facing east. 
visibility is excellent (100 percent) along most of the shoreline, while visibility in the interior is greatly hampered by leaf litter. Soils consist solely of Bibb fine sandy loam with an A-horizon that extends to a depth of 30 centimeters below surface $(\mathrm{cm}$ bs) underlain by a Cg-horizon characterized by long periods of saturation (30-97 cm bs). Based on shovel test data this soil unit is characterized by brown (10YR 5/3) to dark brown (10YR 3/3) sandy loam (0-60 cm bs) underlain by grayish-brown (10YR 5/2) clayish sand (60-80 cm bs).

During the 2017 survey, the shoreline was visually inspected and a sample of surface artifacts was collected. To identify concentrations of artifacts and activity areas the shoreline was arbitrarily divided into nine areas, of varying lengths (Areas 1-9; Figure 5). Collected artifacts were grouped into these predefined areas. Cultural materials collected from the surface include lithic debitage, lithic tools, dart points (Figure 6), arrow points (Figure 7), a pitted stone, a celt fragment, fire-cracked rock (FCR), undecorated ceramic sherds, decorated ceramic sherds, burned clay, fragmented unidentified bone, and domestic historic materials. Table 2 quantifies the results of the surface collection along the shoreline of 41CS125. Based on these results, the highest concentration of artifacts exists along the northern and western shorelines of the site in Areas 1, 2, 3, 4, and 9 .

Following the pedestrian survey, 140 shovel tests were excavated across the 22-acre site, of which 67 tested positive for cultural materials (Figure 8). Artifacts recovered through shovel testing consisted of lithic debitage $(n=239)$, bifaces $(n=2)$, projectile points $(n=3$; Figure 9), ground stone $(\mathrm{n}=2), \mathrm{FCR}(\mathrm{n}=2)$, a ceramic bead (Figure 10), ceramic sherds $(\mathrm{n}=79)$, burned clay, unidentified fragmented bone $(\mathrm{n}=15)$, burned nutshell $(n=3)$, riverine shell fragments $(n=2)$, and a piece of clear vessel glass. Ninety-one percent of the artifacts were recovered from the upper $40 \mathrm{~cm}$ bs. An assessment of artifact density by shovel test shows an increase in artifacts in buried deposits at the northern and western portions of the site (Figure 11), which coincides with the results of the shoreline pedestrian survey.

Three midden-like features were also documented during the investigations of 41CS125 (see Figure 8). Features 1 and 2 are eroded middens characterized by dark-colored soil located at the

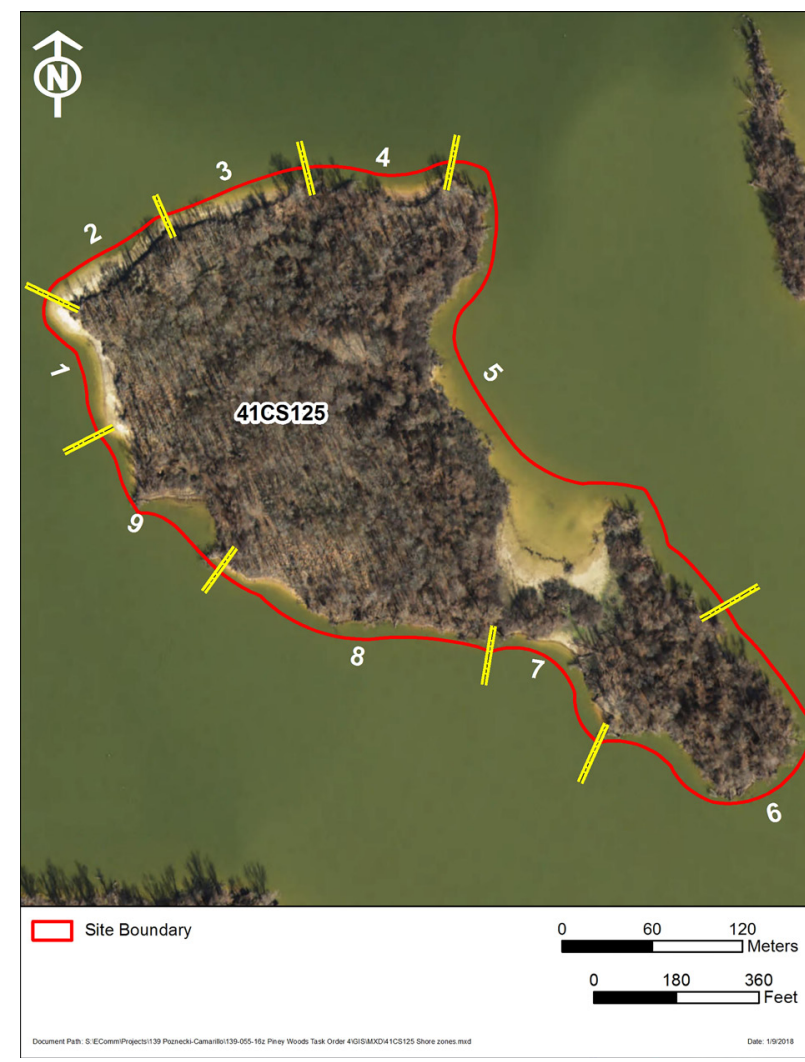

Figure 5. Arbitrarily defined shoreline areas, which aided in the collection of artifacts at $41 \mathrm{CS} 125$.

northern extent of Area 1 (Figure 12). The features measured three meters (north to south) by one meter (east to west) and one meter (north to south) by eight meters (east to west) respectively. An inspection of the subsurface sediments revealed that the darkcolored soil is ephemeral and does not extend below the surface. While artifacts were observed mixed in with the dark-colored soil, there appeared to be no difference in frequency when compared to the rest of the shoreline. These may be the remnants of trash middens, a deliberate accumulation of deposits consisting of copious amounts of organic remains (e.g., charcoal, faunal, nut shell, etc.) and discarded artifacts (e.g., ceramic sherds, lithic debitage, broken stone tools, etc.), that have since eroded away through wave action.

Feature 3 is a midden characterized by a concentration of surface artifacts measuring approximately two meters in diameter. Artifacts observed on the surface consisted of lithic debitage, ceramic sherds, a celt fragment, and domestic historic materials. Shovel Test BN-20 was excavated at the edge of the midden. The shovel test had a yellow brown 


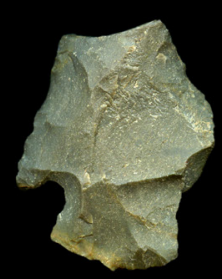

A

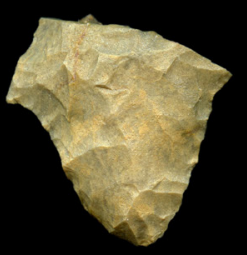

D

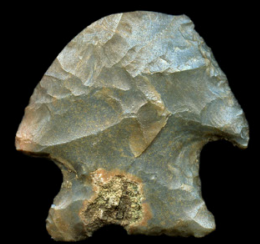

$G$

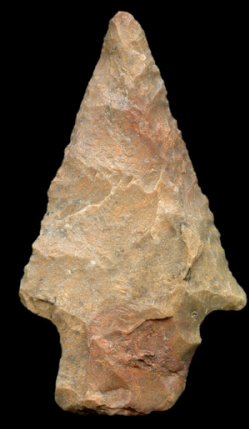

B

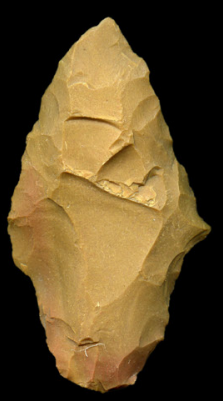

E

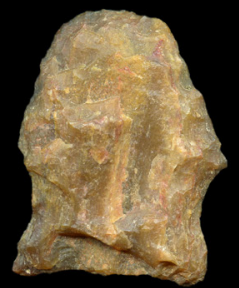

$\mathrm{H}$

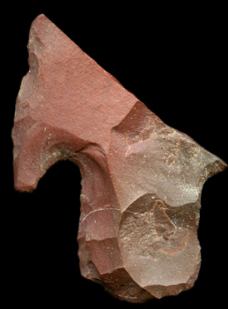

$C$



F

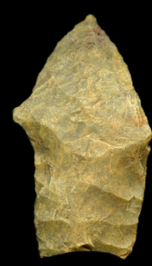

I

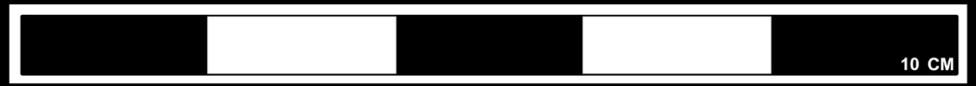

Figure 6. Dart points collected from the surface during the pedestrian survey: A) unidentified Archaic-age projectile point (Area 1); B) unidentified Archaic-age projectile point (Area 2); C) unidentified Archaic-age projectile point (Area 2); D-E) cf. Gary (Area 6); F) cf. Gary (Area 7); G) cf. Edgewood (Area 9); H) cf. San Patrice (Area 9); and I) cf. Gary (Area 9). 


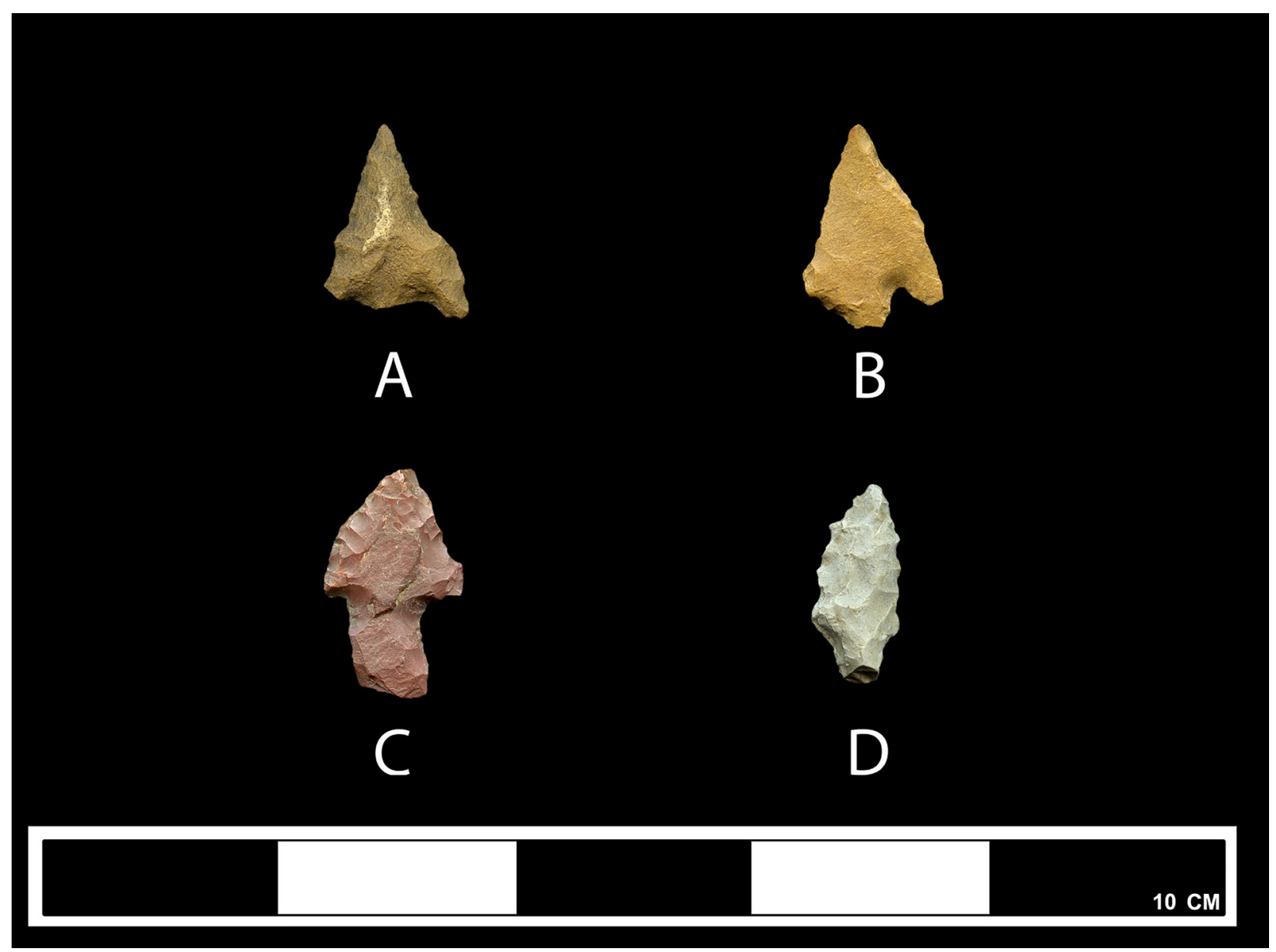

Figure 7. Unidentified ancestral Caddo arrow points collected from areas: A) Area 3; B) Area 4; and C-D) Area 9.

\begin{tabular}{|c|c|c|c|c|c|c|c|c|c|c|c|c|}
\hline Area & LD & LT & PP & PS & CF & FCR & UCS & DCS & BC & FUB & HM & Total \\
\hline 1 & 77 & 8 & 1 & 1 & 0 & 0 & 102 & 22 & 0 & 4 & 3 & 218 \\
\hline 2 & 87 & 5 & 2 & 1 & 0 & 0 & 43 & 14 & 0 & 15 & 1 & 168 \\
\hline 3 & 159 & 4 & 0 & 0 & 0 & 0 & 141 & 34 & 0 & 6 & 0 & 344 \\
\hline 4 & 84 & 6 & 1 & 0 & 1 & 0 & 118 & 28 & 2 & 2 & 34 & 276 \\
\hline 5 & 8 & 1 & 1 & 0 & 0 & 0 & 5 & 0 & 0 & 0 & 7 & 22 \\
\hline 6 & 3 & 1 & 2 & 0 & 0 & 0 & 0 & 0 & 0 & 0 & 0 & 6 \\
\hline 7 & 20 & 0 & 2 & 0 & 0 & 2 & 0 & 0 & 0 & 0 & 5 & 29 \\
\hline 8 & 19 & 0 & 0 & 0 & 0 & 0 & 31 & 4 & 0 & 0 & 1 & 55 \\
\hline 9 & 147 & 4 & 5 & 0 & 0 & 0 & 173 & 94 & 0 & 10 & 7 & 447 \\
\hline Total & 604 & 29 & 14 & 2 & 1 & 2 & 613 & 196 & 2 & 37 & 58 & 1,565 \\
\hline
\end{tabular}

Table 2. Artifacts Recovered During Pedestrian Survey of the Shoreline at 41CS125. LD: Lithic Debitage; LT: Lithic Tool (Bifaces and Projectile Point Fragments); PP: Projectile Point; PS: Pitted Stone; CF: Celt Fragment; FCR: Fire-Cracked Rock; UCS: Undecorated Prehistoric Ceramic Sherd; DCS: Decorated Prehistoric Ceramic Sherd; BC: Burned Clay; FUB: Fragmented Unidentified Bone; and HM: Historic Material. 


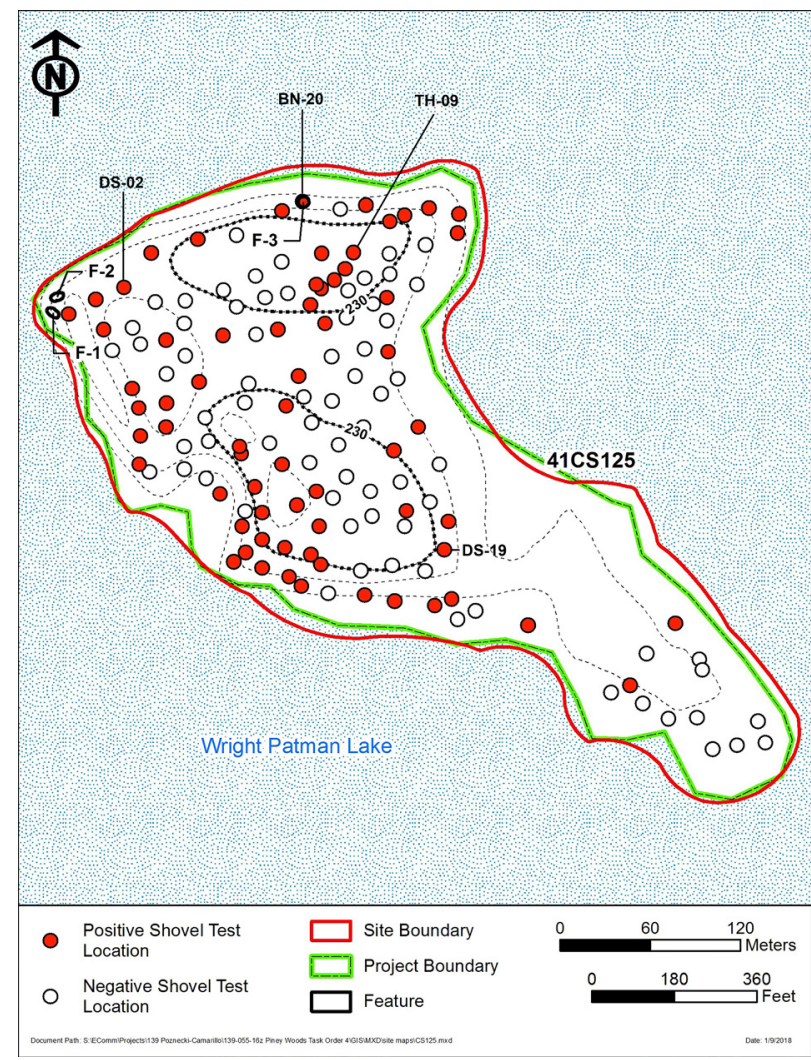

Figure 8 . Site map depicting positive and negative shovel tests at site $41 \mathrm{CS} 125$.

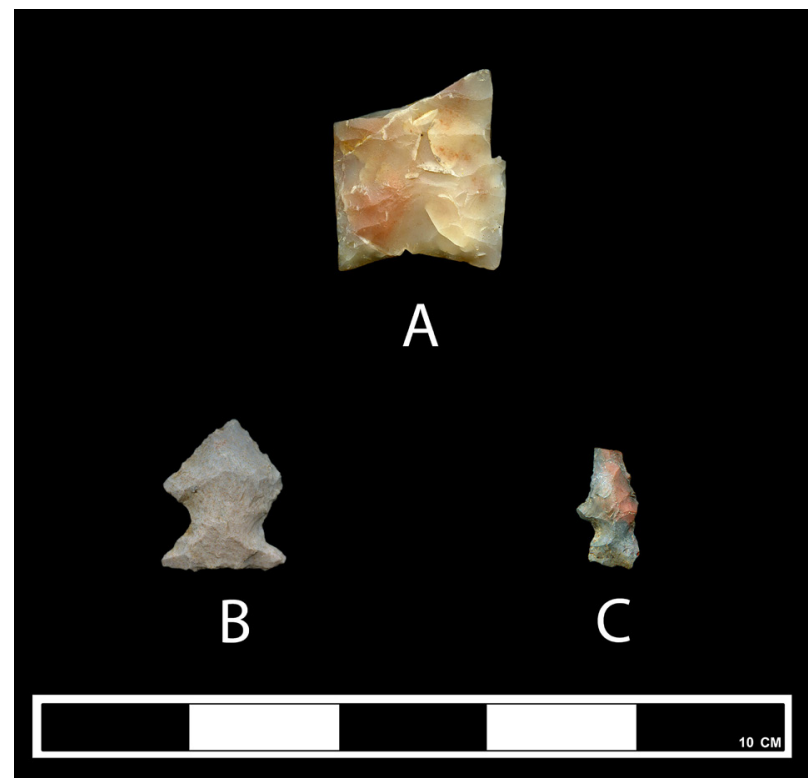

Figure 9. Projectile points recorded during shovel testing: A) a dart point base likely dating to the Paleoindian period recovered from Shovel Test DS-19 (20-40 cm bs); B) an unidentified arrow point found in Shovel Test TH-09 (20-40 $\mathrm{cm} \mathrm{bs}$ ); and C) unidentified arrow point collected from Shovel Test DS-02 (40-60 cm bs).
(10YR 5/6) sandy loam $(0-15 \mathrm{~cm}$ bs) underlain by dark brown (10YR 4/3) sandy loam (15-33 cm bs) overlying gray clay with strong brown mottles. The upper $20 \mathrm{~cm}$ bs contained ancestral Caddo ceramic sherds $(n=2)$ and a single piece of lithic debitage, while between 20 and $35 \mathrm{~cm}$ bs archeologists observed a high frequency of prehistoric cultural materials, which included ancestral Caddo ceramic sherds $(\mathrm{n}=18)$, lithic debitage $(\mathrm{n}=25)$, unidentified bone $(\mathrm{n}=4)$, and a shard of clear glass.

The high concentration of prehistoric cultural material associated with the dark colored subsoil suggests that the midden, or at least a portion of it, remains intact.

\section{Ancestral Caddo Ceramic Analysis}

Ancestral Caddo ceramic sherds are common in both shovel tests $(\mathrm{n}=79)$ and surface collection areas $(\mathrm{n}=809)$ at $41 \mathrm{CS} 125$. A total of 888 ceramic sherds are in the 2017 assemblage from the site (Appendix A). The mean density of ceramics in the 21 shovel tests with ancestral Caddo ceramics at the site is 3.8 (ranging from 1-16 sherds); the highest density of ceramic vessel sherds is in ST BN-20 $(\mathrm{n}=16)$ and ST-BN $21(\mathrm{n}=14)$ in the northeastern part of the site.

In the shoreline areas at $41 \mathrm{CS} 125$, the highest densities of ceramic vessel sherds are in Areas $9(n=281)$ and $3(n=202)$, followed by Areas $4(n=128)$ and Area 1 ( $\mathrm{n}=124)$ (see Appendix A and Figure 5). These are contiguous areas on the western (Areas 1 and 9) and northern (Areas 3 and 4) parts of the alluvial terrace landform or island.

About 95 percent of the ceramic vessel sherds in the shovel tests and surface collection areas are from vessels tempered with grog, either as the sole temper (72 percent), or in combination with burned bone (17.5 percent), hematite (4.2 percent), or bone and hematite (1.0 percent). Approximately 5.0 percent of the sherds are from vessels tempered only with burned bone (see Appendix A). The highest proportions of grog-bonetempered, grog-hematite-tempered, and bone-tempered sherds are in Areas 3 and 4, while the highest proportion of sherds from grog-tempered vessels are in Areas 1,2, and 9 .

Considering the assemblage as a whole, there are 686 plain rim, body, and base sherds and 202 decorated rim and body sherds. The plain to decorated 

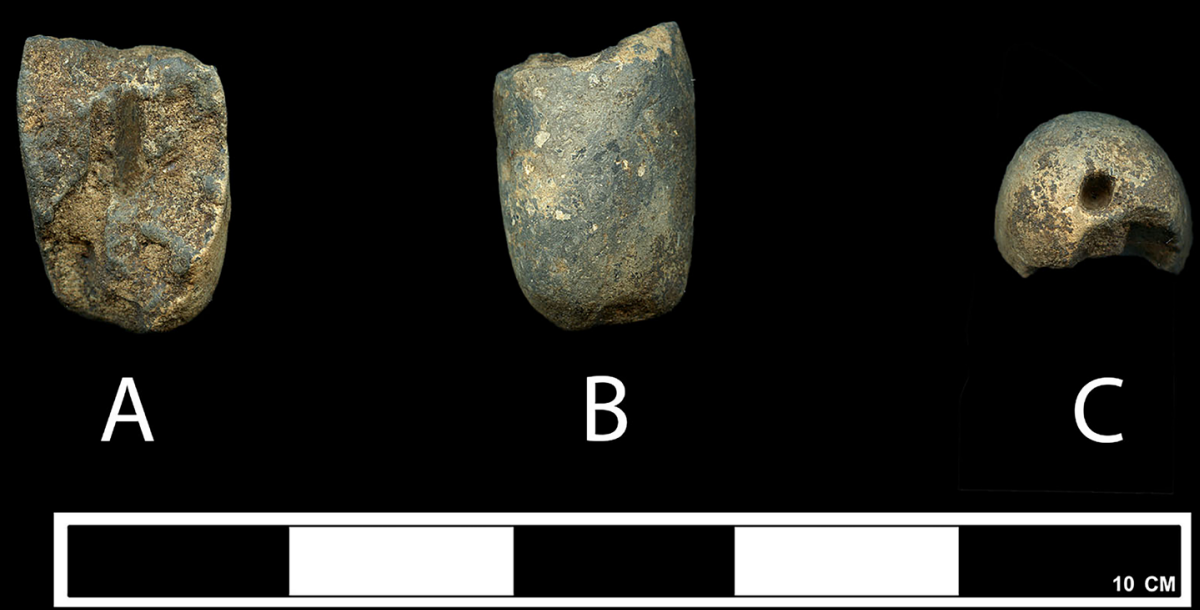

Figure 10. A fragmented ceramic bead recovered from Shovel Test DS-02 (40-60 cm bs): A) interior view; B) exterior view; and C) view of hole opening.

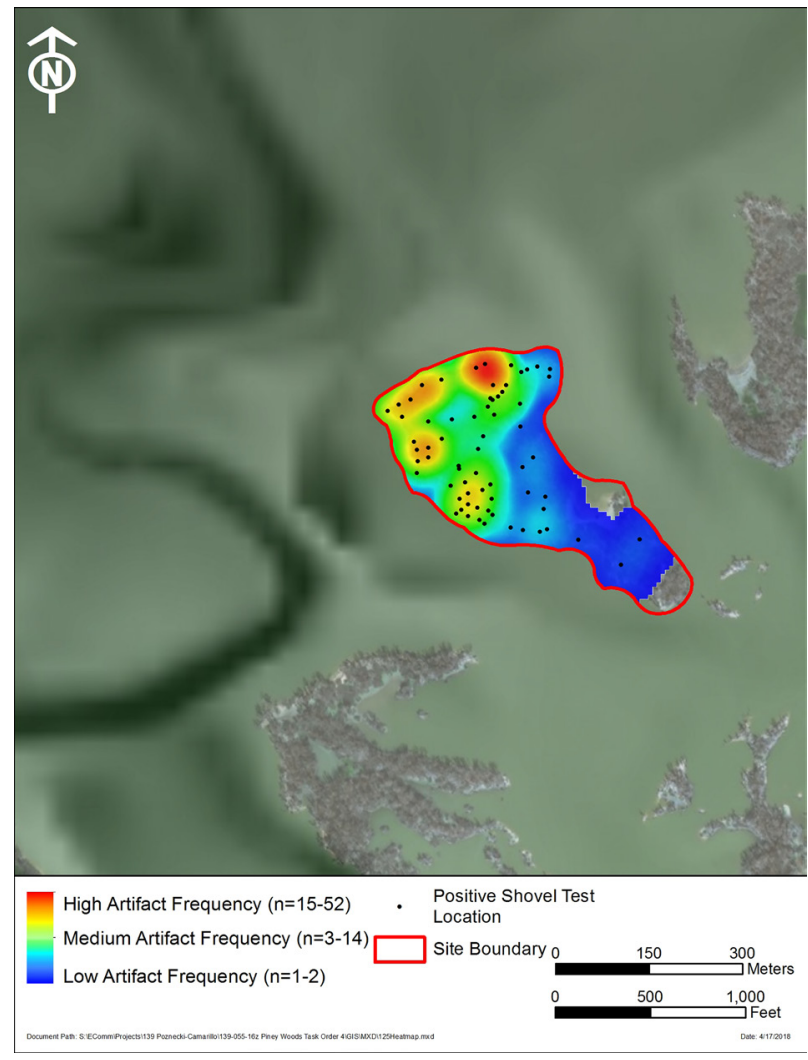

Figure 11. A heat map depicting shovel test artifact density at $41 \mathrm{CS} 125$.



Figure 12. Localized areas of dark-colored soil recorded as middens located at the northern end of Area 1: A) Feature 1, photographed facing north; and B) Feature 2, photographed facing west. 
sherd ratio is 3.40 for the entire assemblage, but ranges from 1.96 in Area 9, 3.57 in Area 4, 4.94 in Area 3, and 5.20 in Area 1. These differences in plain to decorated sherd ratios suggest that Areas 1 and 3 in the northern and northwestern parts of the site (see Figure 5) (with ratios of 5.09-5.20) may have the earliest ancestral Caddo archaeological deposits, while the latest Caddo occupational materials may be in Areas 8 and 9 (with ratios of 1.96-2.00) in the southern and southwestern parts of the site (see Figure 5).

The sherds from decorated ceramic vessels at $41 \mathrm{CS} 125$ are dominated by utility wares, as they comprise 75.7 percent of the decorated sherd sample, and only 24.3 percent of the decorated sherds are from fine wares (Appendix B). About 71 percent of the decorated rim sherds are also from utility ware vessels.

Among the utility wares ( $\mathrm{n}=153)$, more than 41 percent are from vessels with incised decorative elements. Other common utility wares have incisedpunctated (6.9 percent), parallel brushed (6.9 percent), and appliqued (6.4 percent) elements. Overall, almost 15 percent of the decorated sherds from 41CS125 have brushed elements, either as the sole decoration or in combination with appliqued, incised, incised and appliqued, punctated, punctated and incised, and punctated and lip notched decorative elements; 19.7 percent of the utility wares have brushed elements (see Appendix B).

Sherds with appliqued and appliqued-incised decorative elements (see Appendix B) have either parallel or straight appliqued fillet or ridge elements; one body sherd has parallel incised lines adjacent to appliqued ridges. These appliqued body sherds are likely from post-A.D. 1400 McKinney Appliqued, Nash Neck Banded, or Cass Appliqued jars in a Texarkana phase component at $41 \mathrm{CS} 125$. In the surface collections from the site, appliqued sherds are proportionally most common in Area 4 (17.9 percent of the decorated sherds in this assemblage) and Area 9 (7.4 percent).

The recovery of brushed sherds, and sherds with brushed-appliqued, brushed-incised, brushedincised-appliqued, brushed-punctated, brushedpunctated-incised, and brushed-punctated-lip notched decorative elements (see Appendix B), from 41CS125 is indicative of a post-A.D. 1200 or post-A.D. 1400 occupation, given the beginning use of brushing as a decorative element in East Texas Caddo ceramics after that time (Perttula 2015a). The various brushed sherds are from Pease Brushed-Incised (Figure 13a) and Karnack Brushed-Incised (see Figure 13b, g) vessels. Sherds with brushed decorative elements, or combinations of decorative elements are proportionally most common in Areas 3 and 4, except sherds with brushed-punctated elements, which are most common in Areas 9 and 1; located in the northern and western parts of the site shoreline collection areas.

The most distinctive of the incised sherds in the $41 \mathrm{CS} 125$ ceramic assemblage are rim and body sherds from Coles Creek Incised, var. Campbellsville (Figure 14a-b) and var. Mott vessels. The var. Campbellsville sherds have one or two well executed lip lines on a flat lip, while the var. Mott sherds have between two and more than eight overhanging horizontal incised lines (see Figure 14a-d, see also Brown 1988:8). Coles Creek Incised rim and body sherds are present in Areas 3,4 , and 9 at 41CS125. Both varieties of Coles Creek Incised date from ca. A.D. 850-1000, a period of time when Coles Creek Incised sherds are present in certain sites in East Texas, southwest Arkansas, and northwest Louisiana (see Girard 2014: Figure 11), in association with Formative Caddo utility ware and fine ware ceramics. At Lake Wright Patman, Coles Creek Incised sherds and vessels occur in both Late Woodland and Formative/Early Caddo period contexts, most notably at the Snipes site (41CS8, see Jelks 1961; Sitters and Perttula 2017) and the Atlanta State Park or Armstrong Landing site (41CS37, see Harris et al. 1980).

Other incised sherds with horizontal incised lines, but not overhanging, are likely from the ancestral Caddo type Davis Incised (Figure 15a, e). Other rim sherds are from Dunkin Incised vessels with crosshatched or diagonal incised elements (see Appendix B). There are Crockett Curvilinear Incised vessel sherds in the assemblage that have curvilinear hatched zones, horizontal and diagonal incised lines, and horizontal incised lines and a vertical hatched triangle zone (see Figure 15c, f); Crockett Curvilinear Incised sherds are present in Areas 3 and 9.

Among the sherds from incised-punctated vessels is a rim sherd from a Crockett Curvilinear Incised or Pennington Punctated-Incised vessel with cane punctated rows beneath horizontal incised lines 


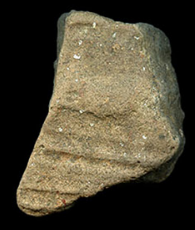

A



B

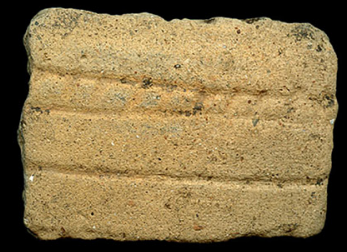

$C$
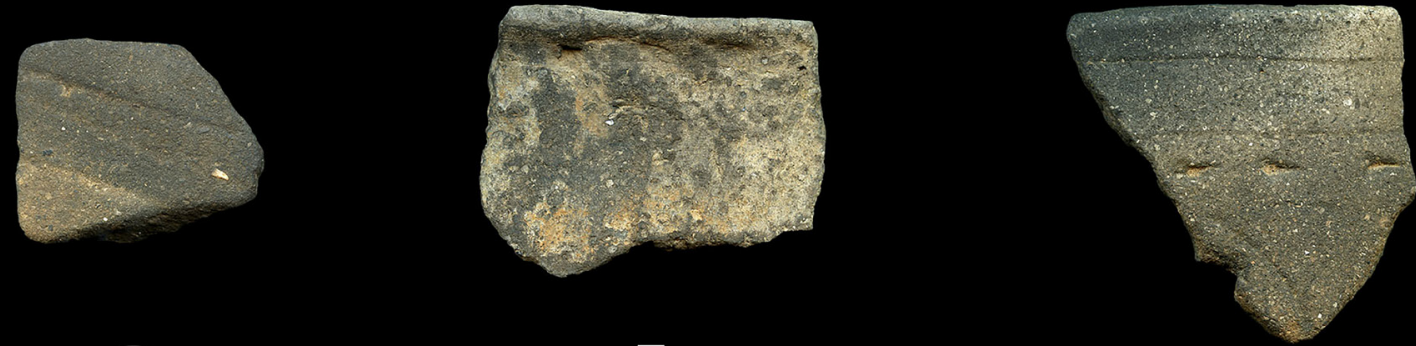

E

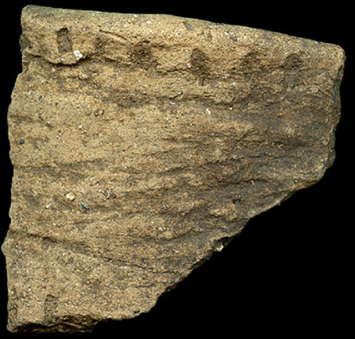

$G$

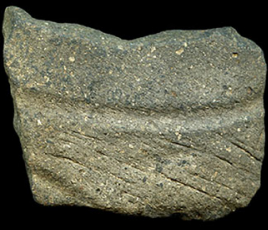

H

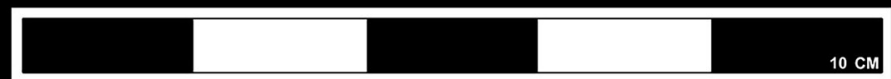

Figure 13. Selected decorated sherds from the Late Caddo period component at 41CS125: A) Pease Brushed-Incised; B) Karnack Brushed-Incised; C-D) Barkman Engraved; E) Nash Neck Banded; F) Barkman Engraved; G) Karnack Brushed-Incised; and H) Hudson Engraved.

(see Figure 15i), and a Weches Fingernail Impressed rim sherd with a horizontal incised line below a fingernail punctated row (see Figure 15j). Another incised-

punctated sherd has diagonal incised lines beneath a row of tool punctations at the lip (see Figure 15b). Incisedpunctated sherds are proportionally most common in
Areas 1 and 3 and may mark, along with Areas 2 and 4 , the core part of the Formative Caddo occupation at $41 \mathrm{CS} 125$.

Three of the decorated sherds in the $41 \mathrm{CS} 125$ sample are from grog-tempered Nash Neck Banded vessels (see Figure 13e). Such vessels were commonly 




Figure 14. Coles Creek Incised sherds from site 41CS125.

manufactured and used by Texarkana phase communities on the Red and Sulphur rivers in East Texas. Nash Neck Banded sherds are present in Areas 1, 2, and 9 of the surface collections at the site.

The punctated rim and body sherds from $41 \mathrm{CS} 125$ were made with a cane (see Figure 15g, right), a Formative to Early Caddo punctated style, fingernails, or tools (see Appendix B and Figure 15g, left); about 4.5 percent of the decorated sherds in the assemblage have punctations.

The fine ware sherds at $41 \mathrm{CS} 125$ have engraved, engraved-punctated, excised, and trailedincised decorative elements (see Appendix B). Among the earliest of the engraved wares is a body sherd from a Spiro Engraved vessel with curvilinear engraved lines and hatched triangle elements (see Figure 15h); this sherd is part of the Formative Caddo component at the site. So too are Hickory Engraved rim and body sherds with horizontal engraved lines (see Figure 15d).

Post-A.D. 1400 engraved and engravedpunctated sherds in the assemblage, particularly those recovered in Area 9 in the surface collections, include rim and body sherds from Barkman Engraved carinated bowls (see Figure 13c-d, f); this area may be the focus of the Late Caddo period Texarkana phase occupation at 41CS125. They have parallel engraved lines and a narrow-hatched zone, rectilinear hatched engraved zones, and horizontal engraved lines above excised punctated rows. Based on comparisons with the decorated ceramics from stratified mound zones at 


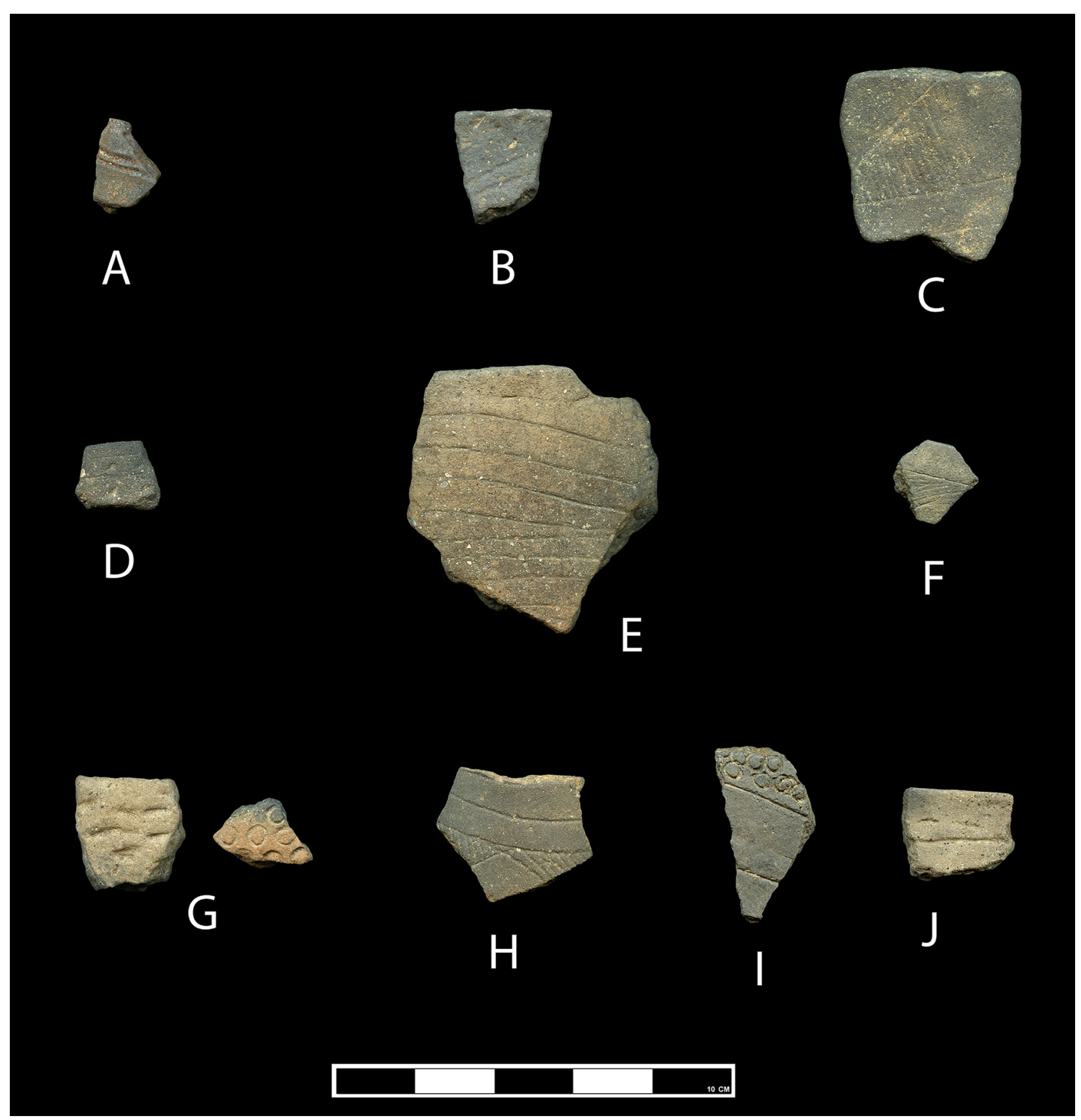

Figure 15. Selected decorated sherds from the ca. A.D. 850-1000 ancestral Caddo component at site 41CS125: A) Davis Incised; B) incised-punctated; C) Crockett Curvilinear Incised; D) Hickory Engraved; E) Davis Incised; F) Crockett Curvilinear Incised; G) left, tool punctated; right, cane punctated; H) Spiro Engraved; I) Crockett Curvilinear Incised or Pennington PunctatedIncised; and J) Weches Fingernail Impressed.

the Hatchel (41BW3) site (Perttula 2018), such vessels are apparently most common in ca. A.D. 1400-1550 Texarkana phase contexts in the Red and Sulphur River basins.

Two sherds have excised elements (see Appendix B), where the surface of a vessel was deliberately scraped away to form part of the decorative element. One sherd from a Barkman Engraved carinated bowl has a row of excised punctations at the carination. The other, from ST DS-03, 20-40 cm bs, has a curvilinear excised area that has been rubbed with a red hematite-rich pigment.

The last of the Late Caddo period fine ware sherds from 41CS125 has broad curvilinear trailed lines 
forming a zone filled with hatched incised lines (see Figure 13h). This sherd is from a Hudson Engraved vessel (see Suhm and Jelks 1962:Plate 41b-c). At the Hatchel site, Hudson Engraved vessels are found in post-A.D. 1650 contexts (see Perttula 2018).

There is also a ceramic sherd collection from 41CS125 held by the Texas Archeological Research Laboratory (TARL); the collection was donated by Janson McVay. In a 1966 letter, McVay noted that he had recovered 46 ceramic vessels, two clay elbow pipes, parts of three long-stemmed Red River pipes, one celt, three bone pins, and nine arrow points, including one of the Bassett type, from the 41 burials he and several other Texarkana collectors excavated at the site (Perttula 2015b). The fact that both elbow pipes and long-stemmed Red River styles pipes were among the funerary offerings in the burials, along with one Bassett arrow point, indicates that the burials at the 41CS125 were interred both before and after ca. A.D. 1400 .

The sherd collection from 41CS125 at TARL includes 129 plain rim, body, and base sherds and 54 decorated rim and body sherds from utility ware and fine ware sherds (Table 3). About 84 percent of the sherds are from grog-tempered vessels and the remaining 16 percent are from bone-tempered vessels.

Almost 70 percent of the decorated sherds $(n=37)$ are from utility ware vessels (Appendix C). Many of these have brushed decorations, either as the sole decorative element $(n=12,32$ percent of the utility ware sherds) or in combination with appliqued $(\mathrm{n}=2)$, incised $(\mathrm{n}=1)$, lip notching $(\mathrm{n}=1)$, or punctated $(n=1)$. These sherds with brushed and other decorative elements comprise another 13.5 percent of the utility ware sherds from 41CS125. These sherds are likely from Pease Brushed-Incised jars. Other common utility ware decorative methods are incised $(n=9,24$ percent of the utility ware sherds), appliqued ( $\mathrm{n}=5,13.5$ percent), and neck banded ( $\mathrm{n}=2,5.4$ percent). The neck banded sherds are from Nash Neck Banded jars while the appliqued sherds are probably from the bodies of McKinney Plain jars.

The fine ware sherds from 41CS125 in the TARL collections all have engraved decorative elements. They include a body sherd from a Hatchel Engraved bottle with oval panels filled with concentric semi-circles; the panels are divided by bracket elements

\begin{tabular}{llll}
\hline Ware & Grog & Bone & N \\
\hline Plain & 105 & 24 & 129 \\
Utility & 33 & 4 & 37 \\
Fine & 15 & 2 & 17 \\
\hline Totals & 153 & 30 & 183 \\
\hline
\end{tabular}

Table 3. Ceramic Assemblage from Site 41CS125 in the TARL Collections.

with a series of embedded negative ovals (Figure 16a). Other engraved bottle sherds have curvilinear lines, as well as horizontal and vertical lines (Figure $16 \mathrm{~g}$ ). The remainder of the engraved sherds from the site are from carinated bowls (Figure 16b-f).

Among the engraved carinated bowl sherds is a rim with a cross-hatched zone below two horizontal lines on the panel (see Figure 16b), as well as a Barkman Engraved sherd with a horizontal scroll marked by narrow hatched zones and a ticked horizontal line above the carination (see Figure 16c). Two other sherds have slanting scroll motifs with excised or hatched triangle elements (see Figure 16d-e), while another has a concentric semi-circle element (see Figure 16f).

Based on the ceramic sherds in the McVay collection, a principal Caddo occupation at 41CS125 appears to have been during the early part of the Late Caddo period (ca. A.D. 1400-1550), during the Texarkana phase. This is based on the proportion of brushed utility wares, as well as the occurrence of defined types such as Barkman Engraved, Cass Appliqued, Hatchel Engraved, McKinney Plain, Nash Neck Banded, and Pease Brushed-Incised (see Perttula 2018). Comparable Late Caddo period ceramics are abundant in the 2017 surface collection at 41CS125; specifically, in Areas 1, 2, 3, 4, and 9. While there are no clear Formative Caddo (ca. A.D. 850-1000) ceramics in the TARL collection, except for a cane punctated sherd, utility ware and fine ware sherds belonging to this component are present from Areas 1, 3, 4, and 9.

A single tubular-shaped ceramic bead was recovered from ST DS-02, $40-60 \mathrm{~cm}$ bs, located at the northern end of the site. The fragment is $25.0+$ millimeters in length, 18.7 millimeters in width, and has a 2.8 millimeters drill hole (see Figure 10). 


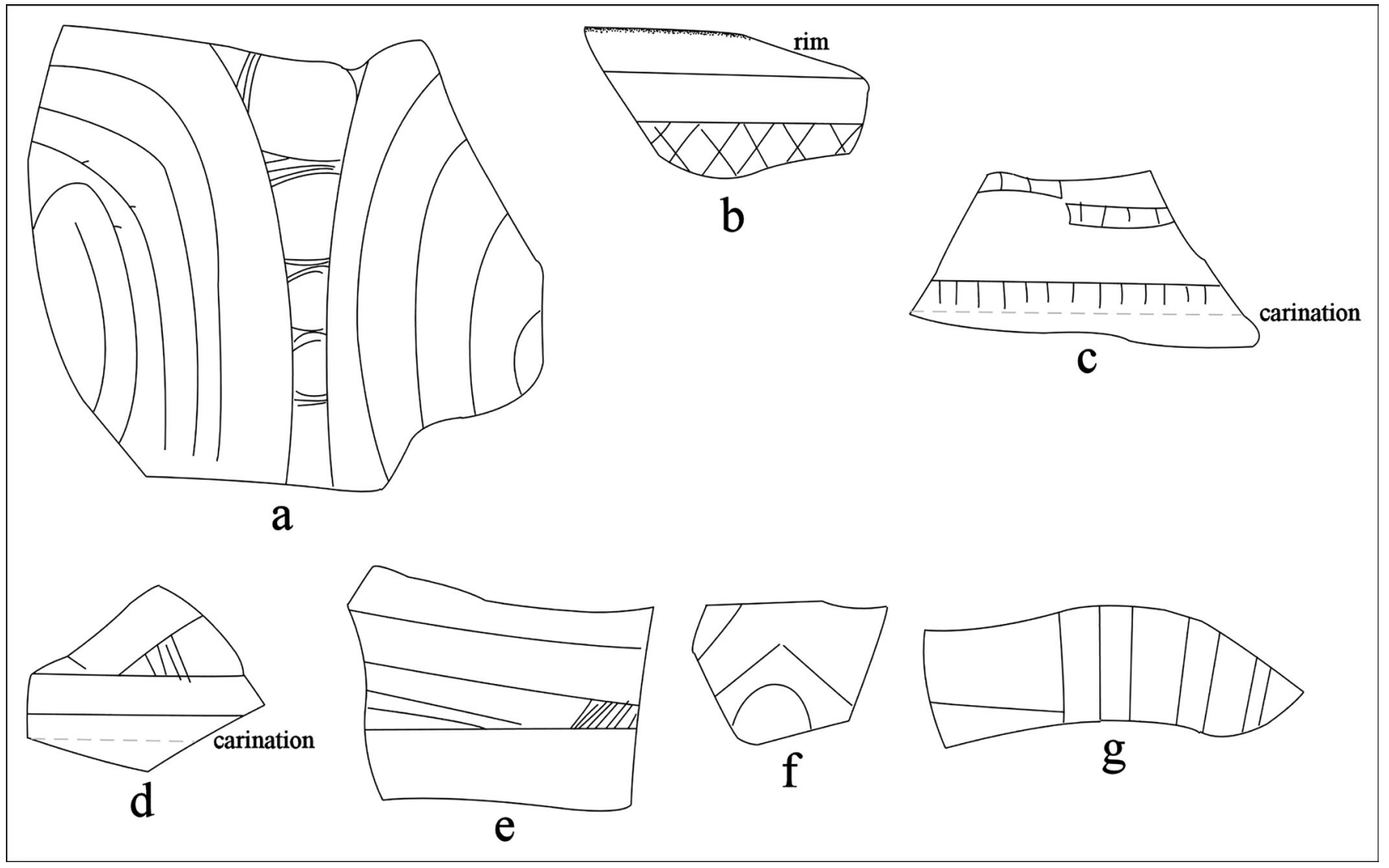

Figure 16. Selected decorative elements in fine ware sherds from the McVay collection at 41CS125: A) Hatchel Engraved bottle sherd; D-F) engraved carinated bowl sherds; and G) engraved bottle sherd.

Ceramic beads as ornaments are rare in the Caddo archeological record in East Texas and Northwest Louisiana (Table 4), and only 14 sites have been identified in a review of the published literature. These 24 beads are both tubular and disc-shaped, and are plain, except for the large "egg-shaped" bead from the Pine Tree Mound site (41HS15) with four sets of incised circles on the body (Fields and Gadus 2012:544-545 and Figure 6.75a-d).

The ceramic beads occur in Formative Caddo (ca. A.D. 850-1000), Middle Caddo (ca. A.D. 12001400), and Late Caddo (ca. A.D. 1400-1680) period assemblages, almost always in habitation contexts, and most commonly in Late Caddo period components. More than half of the ceramic beads are from Late Caddo period contexts. Spatially, the beads are found on sites in the Red River ( $\mathrm{n}=2$ ), Sabine River ( $\mathrm{n}=3$ ), upper and lower Sulphur $(\mathrm{n}=4)$, Big Cypress $(\mathrm{n}=2)$, and the Neches-Angelina River $(\mathrm{n}=3)$ basins.

There are two pieces of burned clay in the 41CS125 artifact assemblage collected during the 2017 work. One is from ST TH-20, 20-40 cm bs, and the other was collected from Area 3.

\section{Historical Research}

The historic-period component of site 41CS125 is part of what was once known as Green Farm, presumably named for a family by the name of Green who owned the property during the nineteenth century. However, deed records documenting a Green family as owners of this property were not found. The earliest deed record located was that documenting a sale of the land from a firm of Morriss and King to J.D. Wilson. Abner Darden Morriss, James Edgar King, and Charlie King were merchants who built a general store at the turn-of-thecentury in the timber town of Munz City, north of State Highway 77 near Farm-to-Market 994. Edgar King was also the town's first postmaster in 1905 (Alford 2010). Morriss and the Kings lived in Munz City and deed records suggest they owned numerous tracts of land around the Sulphur River, likely used as tenant farms and for timber sales.

J.D. Wilson only owned the property for three years before selling it back to Morriss and King in 1920. Eventually, Abner Morriss' son, Berry, sold the land to Chappell Heath, who was related to the Morriss family 


\begin{tabular}{llll}
\hline Site & $\begin{array}{l}\text { No. of } \\
\text { beads }\end{array}$ & Reference & Age \\
& & & \\
\hline 16BO236 & $\mathrm{n}=1$ & Kelley 1997 & Late Caddo period \\
16DS268 & $\mathrm{n}=4$ & Girard 2014; Jensen 1968 & Formative Caddo period \\
41CE19 & $\mathrm{n}=3$ & Newell and Krieger 1949 & Early Caddo period \\
41CS125 & $\mathrm{n}=1$ & This article & possible Formative Caddo \\
& & period \\
41HP175 & $\mathrm{n}=1$ & Fields et al. 1993 & Late Caddo period \\
41HP237 & $\mathrm{n}=2$ & Pertula 2009 & Late Caddo period \\
41HP240 & $\mathrm{n}=3$ & Perttula 2009 & Late Caddo period \\
41HS15 & $\mathrm{n}=1$ & Fields and Gadus 2012 & Late Caddo period \\
41HS240 & $\mathrm{n}=1$ & Perttula and Nelson 1999 & Middle Caddo period \\
41NA236 & $\mathrm{n}=1$ & Perttula 2002 & Late Caddo period \\
41RR16 & $\mathrm{n}=1$ & Perino 1983 & Late Caddo period \\
41SM244 & $\mathrm{n}=2$ & Walters and Perttula 2016 & Middle Caddo period \\
41SM446 & $\mathrm{n}=2$ & Perttula 2017 & Late Caddo period \\
41UR17 & $\mathrm{n}=1$ & Turner 1997 & Middle Caddo period \\
& & & \\
\hline
\end{tabular}

Table 4. Caddo sites in Northwest Louisiana and East Texas with ceramic beads.

by marriage (Berry's sister married a Heath; Find-aGrave 2018). Heath then sold the farm in 1947 to his brother A.O. Heath. None of these landowners lived on the property.

A 1907 topographical map suggests that a house was present at this site at that time, and that it overlooked a natural oxbow of the Sulphur River called "Pine Lake" (Figure 17a). It is possible that this house was part of the old Green Farm. An aerial photograph of the site from 1953 (see Figure 17b) shows that it was a cleared pasture at that time. A possible structure is visible just outside the northern boundary of the site in an overgrown clearing.

Historic-era artifacts from the site included embossed whiteware, banded whiteware, a fragment from a brown-glazed stoneware crock, a milk glass canning jar lid fragment, amethyst glass shards, brown vessel glass shards, and a china doll leg fragment. Of the 60 historic artifacts recovered, 55 were from the surface collections and only five were from shovel tests. More than half of all historic artifacts (58 percent) were recovered from Area 4 at the northern tip of the island. These items are typical of rural households from the late nineteenth through early twentieth centuries, and likely represent occupation of the Green Farm from the time prior to the Morriss and King period of ownership. The artifacts likely pertain to a tenant occupation.

\section{Summary and Conclusions}

Site 41CS125 is an ancestral Caddo site that was occupied extensively during both the Formative to Early Caddo and Late Caddo periods The Late Caddo period component is the principal Caddo occupation documented at the site and is associated with the Texarkana phase in the Red and lower Sulphur River basins. There are no defined phases in the regionally established cultural taxonomy for Red and lower Sulphur River Formative/Early Caddo period cultural groups in this part of East Texas, but the Formative/Early Caddo period component at the site is contemporaneous with the Lost Prairie phase in the Great Bend of the Red River (Schambach 1982). Projectile points recovered at $41 \mathrm{CS} 125$ indicate that the site was also periodically used by Paleoindian, Archaic, and Woodland period groups over many thousands of years.

Once located on an elevated alluvial landform overlooking the Sulphur River to the west, the site is now surrounded by the waters of Lake Wright Patman. As a result, the site has been adversely affected through alluvial erosion. Additionally, the site was extensively looted by collectors who excavated a number of ancestral Caddo burials in the 1950s and 1960s. The recent investigations at the site (Sitters and Perttula 2018) have revealed intact deposits, features, and a large, diverse assortment of artifacts, primarily associated with the ancestral Caddo occupations. The highest frequency of artifacts and features were observed along the site's northern and western boundary. To prevent further erosion, the USACE has lined the banks of the site with riprap.

While no additional work is currently planned at the site given that it is on USACE lands, one future avenue of research may include analysis of collections from the site held privately by past collectors. Certainly, however, if $41 \mathrm{CS} 125$ is to be adversely affected by future USACE undertakings, investigations at the site should focus on a detailed examination of preserved cultural features such as Feature 3. Preserved faunal and floral remains could be informative on Caddo subsistence strategies, most particularly concerning diachronic changes in the importance of maize consumption, since maize became a dietary staple 


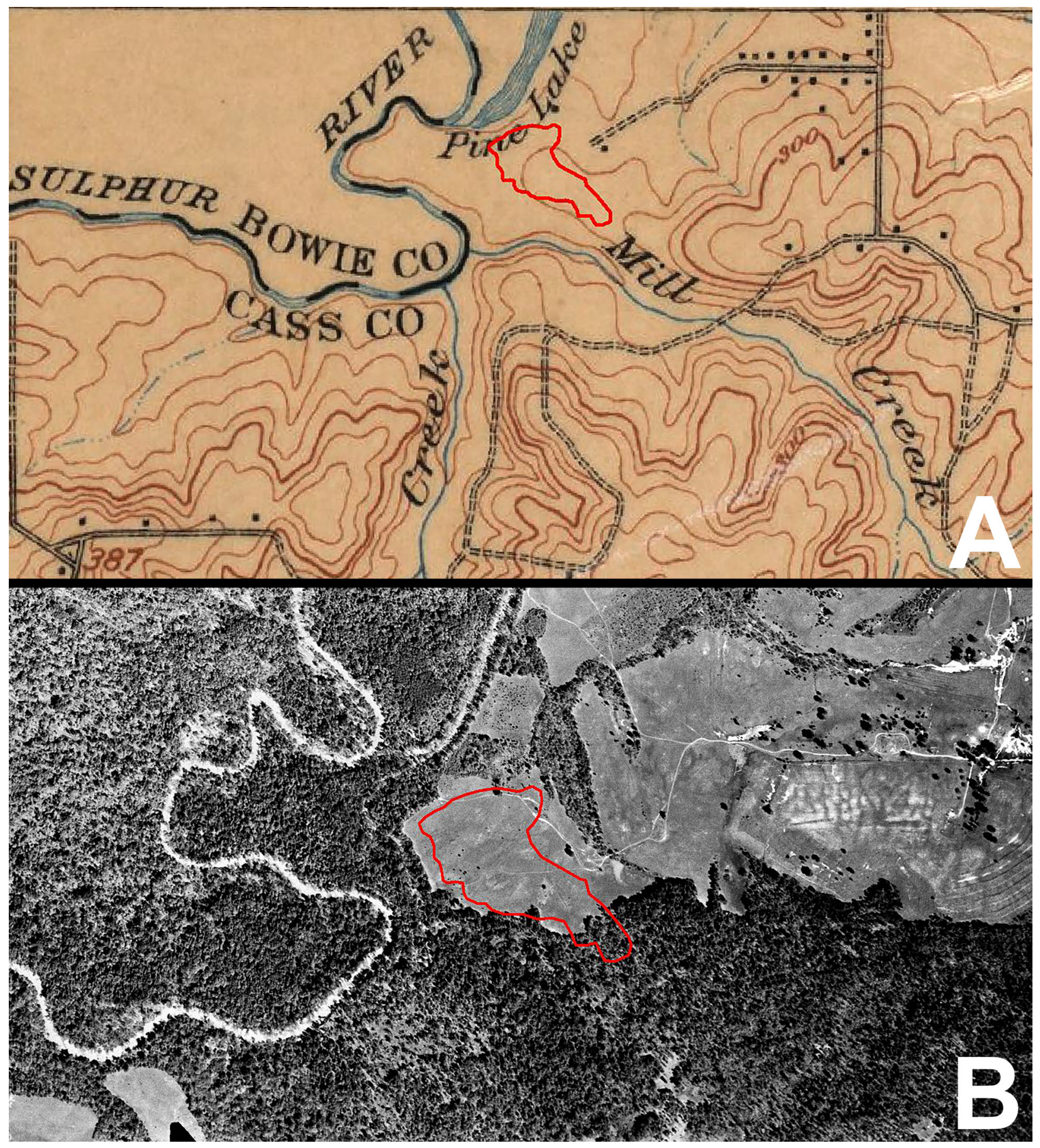

Figure 17. Site 41CS125 depicted on: A) 1907 Atlanta, TX topographic map; and B) 1953 aerial photograph.

for Caddo groups after ca. A.D. 1200/1300. Provided radiocarbon dates can be obtained from controlled contexts, such as the burned nutshell collected during shovel testing, at the site, questions of settlement and subsistence can be best explored in conjunction with the detailed study of the material culture record to better understand the technological, functional, and stylistic character of the assemblage (including petrographic analysis, instrumental neutron activation analysis, and organic residue studies), and if there is evidence for trade/exchange between the ancestral Caddo peoples living at $41 \mathrm{CS} 125$ and other contemporaneous Caddo or non-Caddo groups. 


\section{Acknowledgments}

The authors would like to thank Brian Cockrell, archeologist at the U. S. Army Corps of Engineers, Fort Worth District, Piney Woods Project Office, for his continued efforts to preserve the irreplaceable heritage of Texas. We also thank AmaTerra Environmental, Inc., whose data contributed to the publication of this article. Finally, we appreciate the comments on the MS provided by an anonymous peer reviewer. The exceptional fieldwork was carried out by East Texas archeologists Bo Nelson and Truet Hinson.

\section{References Cited}

Alford, Douglas

2010 “Munz, TX.” In Handbook of Texas Online, accessed online at https://tshaonline.org/handbook/ online/articles/hvmba., January 2018.

Brown, Ian W.

1998 Decorated Pottery of the Lower Mississippi Valley: A Sorting Manual. Mississippi Archaeological Association and Mississippi Department of Archives and History, Jackson.

Dockall, John E., and Ross C. Fields

2006 Reconnaissance Survey to Assess the Impacts on Archeological Resources of the Proposed Conservation Pool Level Rise at Wright Patman Lake, Bowie and Cass Counties, Texas. Reports of Investigations No. 146. Prewitt and Associates, Inc., Austin.

Fields, Ross C., and Eloise F. Gadus (editors)

2012 Archeology of the Nadaco Caddo: The View from the Pine Tree Mound Site (41HS15), Harrison County, Texas. 2 Vols. Reports of Investigations No. 164. Prewitt and Associates, Inc., Austin.

Fields, Ross C., Eloise F. Gadus, L. Wayne Klement, C. Britt Bousman, and Jerrilyn B. McLerran

1993 Excavations at the Tick, Spike, Johns Creek, and Peerless Bottoms Sites, Cooper Lake Project, Delta \& Hopkins Counties, Texas. Reports of Investigations No. 91. Prewitt \& Associates, Inc., Austin.
Find-a-Grave

2018 “Abner Darden Morriss.” Accessed online at https://www.finagrave.com/, January 2018.

Girard, Jeffrey S.

2014 The James Pace Site (16DS268) and Early Caddo Developments Along the Upper Sabine River. Bulletin of the Texas Archeological Society 85:6181.

Harrell, Bryan C., Greg Hendryx, Chris Sypniewski, William Werner, and Jeff Enright

2015 Cultural Resources Management Plan for the Proposed Pool Level Rise at Wright Patman Lake and White Oak Mitigation Area, Texas. SEARCH, Jacksonville, Florida.

Harris, R. King, Inus M. Harris, and Pete Miroir 1980 The Atlanta State Park Site in Northeastern Texas. Louisiana Archaeology 6:231-239.

Jelks, Edward B.

1961 Excavations at Texarkana Reservoir, Sulphur River, Texas. River Basin Survey Papers No. 21. Bureau of American Ethnology, Smithsonian Institution, Washington, D. C.

Jensen, Harold E.

1968 Archaeological Investigations in the Toledo Bend Reservoir: 1966-1967. Archaeology Salvage Project, Southern Methodist University, Dallas.

Kelley, David B.

1997 Two Caddoan Farmsteads in the Red River Valley. Research Series No. 51. Arkansas Archeological Survey, Fayetteville.

Newell, H. Perry, and Alex D. Krieger

1949 The George C. Davis Site, Cherokee County, Texas. Memoirs No. 5. Society for American Archaeology, Menasha, Wisconsin.

Perino, Greg

1983 Archaeological Research at the Bob Williams Site (41RR16), Red River County, Texas. Museum of the Red River, Idabel. 
Perttula, Timothy K.

2009 The Archaeology of the 16th and 17th Century Caddo in the Post Oak Savannah of Northeast Texas: The Tuinier Farm (41HP237), R. A. Watkins (41HP238), and Anglin (41HP240) Sites in the Stouts Creek Basin, Hopkins County, Texas. Journal of Northeast Texas Archaeology 30:1-132.

2015a East Texas Caddo Ceramic Sherd Database. Journal of Northeast Texas Archaeology 51:1-46.

2015b Ancestral Caddo Sites in the lower Sulphur River Basin at Lake Wright Patman, Bowie and Cass Counties, Texas. Journal of Northeast Texas Archaeology 55:19-25.

2017 Analysis of Ancestral Caddo Ceramic Vessel and Pipe Sherds for Sites on the Toll 49 Project, Smith County, Texas. Letter Report No. 344. Archeological \& Environmental Consultants, LLC, Austin.

2018 Analysis of the Hatchel Site (41BW3) Platform Mound Vessels, Vessel Sections, Sherds, Pipes, and Other Clay Artifacts. Special Publication No. 45. Friends of Northeast Texas Archaeology, Austin and Pittsburg.

Perttula, Timothy K. (Editor)

2002 Archeological Investigations at the Proposed Lake Naconiche, Nacogdoches County, Texas. 2 Vols. Report of Investigations No. 42. Archeological and Environmental Consultants, LLC, Austin.

2008 Lake Naconiche Archeology, Nacogdoches County, Texas: Results of the Data Recovery Excavations at Five Prehistoric Archeological Sites. 2 Vols. Report of Investigations No. 60. Archeological \& Environmental Consultants, LLC, Austin.
Perttula, Timothy K., and Bo Nelson

1999 An Archeological Survey of Harrison Bayou Lease Lands at the Longhorn Army Ammunition Plant, Harrison County, Texas. Report of Investigations No. 12. Archeological and Environmental Consultants, Austin.

Sitters, Julian A,. and Timothy K. Perttula

2018 A Cultural Resource Survey of 688 Acres at Sam Rayburn Reservoir and Wright Patman Lake in Cass and San Augustine Counties, Texas. Poznecki-Camarillo, Inc., San Antonio, and AmaTerra Environmental, Inc., Austin.

Schambach, Frank F.

1982 The Archeology of the Great Bend Region in Arkansas. In Contributions to the Archeology of the Great Bend Region, edited by Frank F. Schambach and Frank Rackerby, pp. 1-11. Research Series No. 22. Arkansas Archeological Survey, Fayetteville.

Suhm, Dee A., and Edward B. Jelks (editors)

1962 Handbook of Texas Archeology: Type

Descriptions. Special Publication No. 1, Texas Archeological Society, and Bulletin No. 4, Texas Memorial Museum, Austin.

Turner, Robert L.

1997 Observations on Four Probable Middle Caddo Cemeteries in Camp and Upshur Counties. Journal of Northeast Texas Archaeology 10:12-35.

Walters, Mark, and Timothy K. Perttula

2016 Ceramic Beads from the Cloud Hammond Site (41SM244), Smith County, Texas. Journal of Northeast Texas Archaeology 58:13-14. 
Appendix A. Ceramic Sherds from Site 41CS125.

\begin{tabular}{|c|c|c|c|c|c|c|}
\hline ST & $\begin{array}{l}\text { Depth } \\
\text { cm bs }\end{array}$ & $\begin{array}{l}\mathrm{G} \\
\mathrm{Pl} / \mathrm{Dec}\end{array}$ & $\begin{array}{l}\text { G-B } \\
\text { Pl/Dec }\end{array}$ & $\begin{array}{l}\text { G-H } \\
\text { Pl/Dec }\end{array}$ & $\begin{array}{l}\text { G-B-H } \\
\text { Pl/Dec }\end{array}$ & $\begin{array}{l}\mathrm{B} \\
\mathrm{Pl} / \mathrm{Dec}\end{array}$ \\
\hline BN 20 & $0-20$ & $1 /-$ & - & - & - & $1 /-$ \\
\hline BN 20 & $20-36$ & $8 / 2$ & $4 /-$ & - & - & - \\
\hline BN 21 & $0-20$ & $1 /-$ & $2 / 1$ & - & - & - \\
\hline BN 21 & $20-40$ & $6 /-$ & $3 /-$ & $1 /-$ & - & - \\
\hline BN 29 & $0-20$ & $1 /-$ & - & - & - & - \\
\hline BN 32 & $20-36$ & $1 /-$ & - & - & - & - \\
\hline BN 33 & $20-40$ & $1 /-$ & - & - & - & - \\
\hline BN 34 & $20-40$ & $1 /-$ & - & - & - & - \\
\hline BN 35 & $20-30$ & $1 /-$ & - & - & - & - \\
\hline BN 56 & $0-20$ & $1 /-$ & - & - & - & - \\
\hline BN 57 & $20-35$ & - & $1 /-$ & - & - & - \\
\hline DS 1 & $20-40$ & $4 /-$ & - & - & - & - \\
\hline DS 2 & $0-20$ & $1 /-$ & - & - & - & - \\
\hline DS 2 & $20-40$ & - & $2 /-$ & - & - & - \\
\hline DS 2 & $40-60$ & $-/ 1$ & - & - & - & - \\
\hline DS 3 & $0-20$ & $1 / 1$ & - & - & - & - \\
\hline DS 3 & $20-40$ & $2 / 1$ & - & - & - & - \\
\hline DS 4 & $0-20$ & $3 /-$ & - & - & - & - \\
\hline DS 4 & $20-40$ & - & $3 /-$ & - & - & - \\
\hline DS 4 & $40-60$ & - & - & - & - & $2 /-$ \\
\hline TH 9 & $0-20$ & - & $1 /-$ & - & - & - \\
\hline TH 13 & $0-20$ & - & - & $1 /-$ & - & - \\
\hline TH 15 & $0-20$ & $1 /-$ & - & - & - & - \\
\hline TH 20 & $20-40$ & $2 /-$ & - & - & - & - \\
\hline TH 21 & $20-40$ & $5 / 1$ & $1 /-$ & - & - & - \\
\hline TH 23 & $0-20$ & $-/ 1$ & - & - & - & - \\
\hline TH 29 & $0-20$ & $2 /-$ & - & $1 /-$ & - & - \\
\hline TR 30 & $0-20$ & $5 /-$ & - & - & - & - \\
\hline
\end{tabular}


Appendix A. Surface Collection Areas.

\begin{tabular}{|c|c|c|c|c|c|}
\hline Area 1 & $80 / 19$ & $17 / 1$ & 4/- & - & $3 /-$ \\
\hline Area 2 & $34 / 11$ & $8 / 2$ & $1 /-$ & - & $1 /-$ \\
\hline Area 3 & $105 / 31$ & $47 / 2$ & $3 /-$ & $1 /-$ & $12 / 1$ \\
\hline Area 4 & $61 / 18$ & $24 / 4$ & $4 / 3$ & $-/ 2$ & $11 / 1$ \\
\hline Area 5 & $5 /-$ & - & - & - & - \\
\hline Area 8 & $7 / 4$ & - & - & - & $1 /-$ \\
\hline Area 9 & $131 / 81$ & $29 / 4$ & $11 / 8$ & $5 / 1$ & $10 / 1$ \\
\hline Totals & $471 / 171$ & $142 / 14$ & $26 / 11$ & $6 / 3$ & $41 / 3$ \\
\hline
\end{tabular}


Appendix B. Decorative methods and elements represented in the 41CS125 ceramic sherd Assemblage.

Decorative Method and Element

Rim Body N

\section{Utility Ware}

\section{Appliqued}

parallel appliqued ridges

straight appliqued fillet

straight appliqued ridge

\section{Appliqued-Incised}

appliqued ridges-parallel incised lines

$\begin{array}{ll}- & 1 \\ - & 5 \\ - & 7\end{array}$

\section{Brushed}

parallel brushed marks

\section{Brushed-Appliqued}

parallel brushed marks-straight appliqued fillet

$\begin{array}{lll}- & 2 & 2\end{array}$

\section{Brushed-Incised}

horizontal brushed-incised marks and lines

$1-1$

parallel brushed-incised marks and lines

-5
-5

\section{Brushed-Incised-Appliqued}

parallel brushed marks-incised-straight appliqued ridge

(Pease Brushed-Incised)

\section{Brushed-Punctated}

$\begin{aligned} & \text { horizontal brushed marks-tool punctated row at the lip } \\ & \text { horizontal brushed marks-tool punctated row at rim- }\end{aligned}$
$\begin{aligned} & - \\ & \text { body juncture }\end{aligned}$
$\begin{aligned} & \text { parallel brushed marks-tool punctated row through the } \\ & \text { brushing }\end{aligned}$
$\begin{aligned} & \text { vertical brushed-marks-tool punctated row at rim-body } \\ & \text { juncture }\end{aligned}$




\begin{tabular}{lll}
\hline Decorative Method and Element $\quad$ Rim Body N \\
\hline
\end{tabular}

\section{Brushed-Punctated-Incised}

parallel brushed marks-tool punctated row-diagonal $\quad$ - $\quad 1 \quad 1$ incised lines

\section{Brushed-Punctated-Lip Notched}

horizontal brushed marks-tool punctated rows through $\quad 1 \quad$ - 1

the brushing-lip notched

\section{Incised}

closely-spaced horizontal incised lines

cross-batched incised lines

curvilinear hatched zone (Crockett Curvilinear)

$1-1$

$1 \quad 1 \quad 2$

Incised)

diagonal incised lines

broad horizontal incised lines

horizontal incised line/lines

$2+$ horizontal incised lines, overhanging (Coles Creek

$\begin{array}{lll}1 & 1\end{array}$

Incised)

$8+$ horizontal incised lines, overhanging (Coles Creek

$-1$

1

Incised)

$2+$ closely-spaced horizontal incised lines

$3+$ horizontal incised lines

$\begin{array}{ll}-1 & 1\end{array}$

$6+$ horizontal incised lines

$1 \quad-\quad 1$

$8+$ horizontal incised lines

1 - 1

horizontal-diagonal incised lines (Crockett Curvilinear

$2 \quad-\quad 2$

Incised)

horizontal-vertical incised lines

horizontal incised lines and vertical hatched triangle

$-1$

1

zone (Crockett Curvilinear Incised) 


\begin{tabular}{|c|c|c|c|}
\hline \multicolumn{4}{|l|}{ Incised (cont.) } \\
\hline one incised lip line (Coles Creek Incised) & 1 & . & 1 \\
\hline two incised lip lines (Coles Creek Incised) & 1 & - & 1 \\
\hline opposed incised lines & - & 3 & 3 \\
\hline closely-spaced parallel incised lines & - & 2 & 2 \\
\hline parallel incised lines & $=$ & 37 & 37 \\
\hline parallel incised lines, overhanging lines (Coles Creek) & $=$ & 3 & 3 \\
\hline straight incised line & $=$ & 9 & 9 \\
\hline straight incised line on interior vessel surface & - & 1 & 1 \\
\hline \multicolumn{4}{|l|}{ Incised-Punctated } \\
\hline curvilinear incised zone with circular punctations & $=$ & 1 & 1 \\
\hline diagonal incised lines-tool punctated row at lip & $=$ & 1 & 1 \\
\hline $\begin{array}{l}\text { diagonal opposed incised lines with vertical tool } \\
\text { punctated row between }\end{array}$ & $=$ & 1 & 1 \\
\hline horizontal incised lines above cane punctated rows & 1 & - & 1 \\
\hline $\begin{array}{l}\text { horizontal incised line below fingernail punctated row } \\
\text { (Weches Fingernail Impressed) }\end{array}$ & 1 & - & 1 \\
\hline horizontal incised lines above tool punctated row & - & 1 & 1 \\
\hline horizontal incised lines-tool punctated row at the lip & 1 & - & 1 \\
\hline $\begin{array}{l}\text { horizontal-diagonal incised lines-tool punctated-filled } \\
\text { triangular zone }\end{array}$ & - & 1 & 1 \\
\hline $\begin{array}{l}\text { parallel incised lines between zones with incised cane } \\
\text { punctations }\end{array}$ & - & $\mathbf{1}$ & 1 \\
\hline parallel incised lines and zone of cane punctations & - & $\mathbf{1}$ & 1 \\
\hline parallel incised lines above tool punctated row/rows & - & 2 & 2 \\
\hline $\begin{array}{l}\text { straight incised line and rows of triangular-shaped tool } \\
\text { punctations }\end{array}$ & - & $\mathbf{1}$ & 1 \\
\hline vertical incised line-tool punctated row & - & 1 & 1 \\
\hline
\end{tabular}


Decorative Method and Element

Rim Body N

Neck Banded

borizontal neck bands

parallel neek bands (Nash Neck Banded)

$1 \quad 1$

Punctated

cane punctated rows

fingernail punctated row

linear tool punctated rows

tool punctated row/rows

- 2

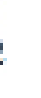

$\begin{array}{lll}- & 1 & 1 \\ 1 & 1 & 2 \\ - & 2 & 2 \\ - & 4 & 4\end{array}$

\section{Fine Ware}

Engraved

circular engraved el. and hatched triangle el.

cross-hatched engraved zone

curvilinear engraved line/lines

curvilinear engraved lines-open pendant triangle el.

curvilinear engraved lines-hatched triangle el.

$\begin{array}{lll}= & 1 & 1 \\ = & 1 & 1 \\ = & 5 & 5 \\ = & 2 & 2 \\ = & 1 & 1\end{array}$

\section{(Spiro Engraved)}

curvilinear hatched zones

diagonal engraved lines

hatched triangle element

borizontal engraved line beneath the lip

borizontal engraved lines

borizontal-curvilinear engraved lines

$\begin{array}{lll}-1 & 1\end{array}$

borizontal engraved lines-curvilinear hatched zone

1

$\begin{array}{lll}-1 & 1\end{array}$

2 - 2

$\begin{array}{lll}7 & 1 & 8\end{array}$

- 11

borizontal-vertical engraved lines

$1-1$

opposed engraved lines

- 22

parallel engraved lines

sets of parallel engraved lines

1

1

5

2

1

1

2

8

1

1

2

- 11

- 22

$\begin{array}{ll}- & 1\end{array}$ 


\begin{tabular}{|c|c|c|c|}
\hline Decorative Method and Element & Rim & Body & $\mathrm{N}$ \\
\hline \multicolumn{4}{|l|}{ Engraved (cont.) } \\
\hline $\begin{array}{l}\text { parallel engraved lines and narrow hatched zone } \\
\text { (Barkman Engraved) }\end{array}$ & - & 2 & 2 \\
\hline rectilinear hatched engraved zone (Barkman Engraved) & - & 1 & 1 \\
\hline semi-circular el. with internal vertical engraved line & - & 1 & 1 \\
\hline straight engraved line & - & 8 & 8 \\
\hline \multicolumn{4}{|l|}{ Engraved-Punctated } \\
\hline $\begin{array}{l}\text { horizontal engraved lines above excised punctated row } \\
\text { (Barkman Engraved) }\end{array}$ & 1 & - & 1 \\
\hline straight engraved line-excised punctated row & - & 1 & 1 \\
\hline \multicolumn{4}{|l|}{ Excised } \\
\hline curvilinear excised area-rubbed with red pigment & - & 1 & 1 \\
\hline $\begin{array}{l}\text { excised punctated row at carina } \\
\text { (Barkman Engraved) }\end{array}$ & - & 1 & 1 \\
\hline \multicolumn{4}{|l|}{ Trailed-Incised } \\
\hline $\begin{array}{l}\text { broad curvilinear trailed lines-incised hatched zone } \\
\text { (Hudson Engraved) }\end{array}$ & - & 1 & 1 \\
\hline Totals & 41 & 161 & 202 \\
\hline
\end{tabular}


Appendix C. Decorated sherds from site 41 CS125 in the TARL collections.

Decorative Method/ Grog Bone N
Decorative Element

\section{Appliqued}

straight appliqued fillet

straight appliqued ridge

1

4

1

\section{Brushed}

opposed brushing marks

parallel brushing marks

1

10

\section{Brushed-Appliqued}

parallel brushed-straight appliqued fillet

1

parallel brushed-straight appliqued ridge

1

\section{Brushed-Incised}

parallel brushed-incised

1

\section{Brushed-Lip Notched}

horizontal brushed on rim; lip notehed

1

\section{Brushed-Punctated}

horizontal brushed-tool punctated rows under

the lip and at rim-body juncture

\section{Incised}

cross-hatched lines

diagonal opposed lines

1

horizontal line or lines

parallel lines

1

straight lines

2

1

\section{Incised-Appliqued}

vertical and opposed lines and a vertical appliqued ridge 


\begin{tabular}{llll}
\hline Decorative Method/ & Grog & Bone & N \\
Decorative Element & & & \\
& & \\
\end{tabular}

\section{Incised-Punctated}

parallel lines and adjacent tool punctated row

$\begin{array}{lll}1 & - & 1\end{array}$

\section{Neck Banded}

horizontal neck banding

2

2

Punctated

cane punctated rows/zone

circular punctated rows

$1 \quad-\quad 1$

\section{Fine Ware}

\section{Engraved}

concentric semi-circles

concentric semi-circles and brackets with

1

negative ovals

curvilinear lines

horizontal lines

horizontal lines and cross-hatched zone

horizontal scroll with hatched zones and

horizontal line with tick marks

horizontal lines and slanting scroll; batched

112

triangle element

horizontal and vertical lines

$1 \quad-\quad 1$

parallel lines

straight line

$1 \quad 1 \quad 2$

$3 \quad-\quad 3$

Totals

48

6

54 